\title{
PEMBELAJARAN MATAPELAJARAN BIOLOGI MATERI LINGKUNGAN DI SEKOLAH MENGENGAH ATAS DAN DAYA DUKUNGNYA TERHADAP LITERASI LINGKUNGAN SISWA
}

\author{
Prasetiyo \\ Program Studi Pendidikan Biologi FPMIPATI Universitas PGRI Semarang \\ email: tiyopras@ymail.com
}

Diterima 3 September 2017 disetujui 13 Oktober 2017

\begin{abstract}
The purpose of this study is to know the learning and the carrying capacity of environmental literacy on the subject of environmental biology at Senior High School, apply the type of qualitative research and use purposive sampling in sampling, data collection by questioner and interview. The results showed that the learning done by the teacher has not fully supported the optimization of students' literacy.
\end{abstract}

Keywords: biology learning, environmental literacy

\section{PENDAHULUAN}

Literasi lingkungan merupakan kemampuan dari setiap individu dalam memahami dan menafsirkan kondisi lingkungan, dari hasil pemahaman dan penafsiran tersebut setiap indivdu dapat memutuskan tindakan yang tepat dalam mempertahankan, memulihkan serta meningkatkan kondisi suatu lingkungan (Holdaway, 1978). Selain itu Fidan (2016) menjelaskan bahwa literasi lingkungan merupakan sebuah persepsi serta keaktivan individu dalam melakukan tindakan terkait lingkungan. Literasi lingkungan dapat dipahami juga sebagai pengetahuan, kesadaran, kepekaan dan tanggung jawab pengaruh akivitas individu terhadap sumber daya alam (Derman, Sahin, dan Hacieminoglu, 2016). Berdasarkan beberapa definisi tersebut dapat dipahami literasi lingkungan merupakan kemampuan dari setiap individu terkait dengan pengetahuan, keterampilan dalam berpikir, sikap dan bagaimana memberikan perilaku terhadap lingkungan.

Abad 21 merupakan abad yang membutuhkan sumber daya manusia yang berkompeten. Kompetensi sumber daya dapat diperhatikan dari kemampuan terkait 4 Cs, literasi, kecakapan hidup, karakter. Literasi termasuk di dalamnya adalah literasi terhadap lingkungan AACTE, 2010). Dengan literasi lingkungan seseorang baik sebagai individu maupun kelompok dapat mengantisipasi dan mengatasi permasalahan lingkungan.

Memperhatikan pentingnya kemampuan literasi lingkungan untuk dimiliki oleh setiap individu, dengan harapan kehidupan di alam dapat mengalami keberlanjutan, maka perlu juga diketahui bagaimanakah literasi siswa terhadap lingkungan. Literasi lingkungan terdiri dari empat bagian yaitu pengetahuan siswa tentang lingkungan, keterampilan kognitif siswa, sikap dan perilaku siswa terhadap lingkungan. Berdasarkan empat komponen tersebut diketahui bahwa terdapat kecenderungan pengetahuan siswa tentang lingkungan mengalami penurunan setiap terjadi peningkatan level kelas siswa (Asan, 2014), selain itu terdapat korelasi yang rendah antara pengetahuan lingkungan 
dengan perilaku siswa terhadap lingkungan (Haske, 2016). Hal ini menunjukkan bahwa tingginya pengetahuan tentang lingkungan siswa belum sepenuhnya dapat membentuk perilaku setiap individu, dengan pernyataan lain setiap bagaian dari literasi lingkungan belum dapat saling memberikan penguatan.

Kemungkinan apa yang akan terjadi jika literasi lingkungan tidak dimiliki siswa. (Rahmawati, 2016; Abrauw, 2011) menjelaskan bahwa masyarakat pada umum berperilaku sebagaimana kebiasaan yang dilakukan, dan perilaku tersebut bersifat turun temurun atau menjadi sebuah budaya. Maka kemungkinan yang akan terjadi jika kerusakan lingkungan sudah terjadi maka kerusakan lingkungan berikutnya akan terjadi.

Terdapat berbagai penjelasan mengapa literasi lingkungan belum optimal. Fidan (2016) menjelaskan pembelajaran belum dapat mengoptimalkan literasi lingkungan siswa dikarenakan proses kegiatan belajar mengajar belum melibatkan aktivitas yang dapat membangun literasi lingkungan siswa. Loubser, Swanepoel dan Chacko, (2001) menyatakan terdapat beberapa alasan meliputi 1) guru belum menekankan pendidikan lingkungan 2) guru belum memiliki informasi tentang pendidikan lingkungan 3) kurangnya penggunaan metode dan strategi pembelajaran yang digunakan guru 4) kemampuan guru dalam mengikuti berbagai perubahan.

Berdasarkan latar belakang maka tujuan penelitian ini adalah untuk mengetahui bagaimanakah pembelajaran dan daya dukungnya terhadap literasi lingkungan siswa pada matapelajaran biologi materi lingkungan di SMA

\section{METODE}

Jenis penelitian yang diterapkan adalah penelitian kualitatif, lokasi penelitian di Sekolah Menengah Atas di Kecamatan Comal. Subjek penelitian adalah guru matapelajaran biologi, instrumen yang dipergunakan adalah quesioner dan lembar wawancara, analisis penelitian dengan langkah reduksi data, penyajian data, kesimpulan dan verifikasi.

\section{HASIL DAN PEMBAHASAN}

Berdasarkan analisis hasil quesioner dan wawancara diketahui bagaimanakah pembelajaran yang dilakukan guru pada matapelajaran biologi materi lingkungan. Hasil penelitian tertuang di dalam Tabel 1. Tabel 1. Data Pembelajaran Guru pada Materi Lingkungan

\begin{tabular}{lll}
\hline \multicolumn{1}{c}{ Komponen pengamatan } & \multicolumn{1}{c}{ Temuan } & \multicolumn{1}{c}{ Keterangan } \\
\hline Penggunaan model pembelajaran & $\begin{array}{l}\text { Guru menerapkan model } \\
\text { pembelajaran inquiry }\end{array}$ & $\begin{array}{l}\text { Model pembelajaran inquiry } \\
\text { diterapkan 1-2 kali dalam satu } \\
\text { semester } \\
\text { Penggunaan metode ceramah }\end{array}$ \\
$\begin{array}{lll}\text { Guru menerapkan metode } \\
\text { ceramah }\end{array}$ & $\begin{array}{l}\text { Metode ceramah yang } \\
\text { dikombinasi dengan icebreaking } \\
\text { sangat sering diterapkan guru }\end{array}$ \\
Penggunaan media pembelajaran & $\begin{array}{l}\text { Guru menggunakan media benda } \\
\text { nyata, benda tiruan, poster }\end{array}$ & $\begin{array}{l}\text { Media dalam bentuk video, } \\
\text { gambar, grafik masih belum } \\
\text { dioptimalkan }\end{array}$ \\
& Pengolahan materi & $\begin{array}{l}\text { Belum keseluruhan guru } \\
\text { mengkontekstualkan materi }\end{array}$ \\
Kendala dalam pembelajaran & Memberikan contoh kegiatan di & $\begin{array}{l}\text { Belum keseluruhan guru } \\
\text { memanfaatkan perkembangan } \\
\text { informasi kekinian untuk }\end{array}$ \\
& lingkungan & mendukung materi lingkungan \\
\hline
\end{tabular}


BerdasarkanTabel1.diketahuibahwa dalam membelajarkan materi lingkungan guru lebih banyak menggunakan metode ceramah yang dikombinasikan dengan ice breaking, sedangkan penggunaan model-model pembelajaran yang variatif belum dioptimalkan. Diperoleh keterangan mengapa guru lebih banyak menerapkan metode ceramah dari pada model pembelajaran yang variatif, guru menjelaskan bahwa dengan metode ceramah waktu untuk menyampaikan materi lebih efisien. Temuan pembelajaran guru pada materi lingkungan ini menunjukkan bahwa belum sepenuhnya pembelajaran yang dilaksanakan oleh guru menunjang peningkatan literasi lingkungan siswa.

Terdapat beberapa upaya yang dapat dilakukan untuk mengoptimalkan literasi lingkungan diantaranya dengan melakukan penataan kurikulum (Clarabel, 2014; Karimzadegan \& Meiboudi, 2012), pembelajaran memberikan pengalaman langsung yang didukung pembelajaran aktif dengan menggunakan berbagai metode variatif dan pelaksanaannya dapat dilakukan di dalam maupun di luar kelas (Every \& Student, 2015; Derman et al., 2016; Castelli, Barcelona, \& Bryant (2015).

Penggunaan metode pembelajaran perlu dioptimalkan dengan memanfaatkan media pembelajaran. Saran mendia pembelajaran yang digunakan untuk mengoptimalkan literasi lingkungan siswa adalah media yang menarik, memotivasi, menyenangkan dan terdapat kombinasi aktivitas membaca siswa dan alat bantu yang dapat digunakan diantaranya berupa e-learning (Ozge, Moseley, \& Cigdemoglu, 2011; Luppi, 2011). Temuan pembelajaran yang dilakukan oleh guru adalah guru telah memanfaatkan media dengan benda nyata, benda tiruan dan poster. Berdasarkan karakteristik media yang disarankan maka perlu adanya pengoptimalan media pemelajaran guru yang dapat menstimulus siswa untuk aktif dalam melakukan aktivitas membaca.

Gurudalammelakukan pembelajaran selain mengoptimalkan penggunaan model, metode, media pembelajaran hal penting lain yang perlu menjadi perhatian guru adalah menggunakan informasi baru untuk menambah pengetahuan siswa. Berkaitan dengan ini berdasarkan hasil penelitian menunjukkan bahwa dalam melakukan pembelajaran guru memberikan contoh kegiatan di lingkungan, belum menambahkan informasi-informasi kekinian.

\section{SIMPULAN}

Simpulan dari penelitian ini adalah jika dibandingkan antara pembelajaran yang dilakukan guru dengan rekomendasi para peneliti dik etahui pembelajaran yang dilakukan belum sepenuhnya mendukung untuk pengoptimalan literasi lingkungan siswa. Hasil penelitian ini akan ditindaklanjuti oleh peneliti pada langkah penelitian selanjutnya.

\section{DAFTAR PUSTAKA}

AACTE. (2010). 21st Century Student Outcomes. Retrieved from http:// www.p21.org/storage/documents/ aacte_p21_whitepaper2010.pdf

Abrauw, A. E. S. (2011). Perilaku Masyarakat Dalam Pengelolaan Sampah Anorganik di Kecamatan Abepura Kota Jayapura. MGI, 25(1), $1-14$.

Asan, I., Mile, S., \& Ibraim, J. (2014). Attitudes of Macedonian High School Students towards the environment. Procedia-Social and Behavioral Sciences, 159, 636-642

Castelli, D. M., Barcelona, J. M., \& Bryant, L. (2015). ScienceDirect Contextualizing physical literacy in the school environment: The challenges. Journal of Sport and Health Science, 4(2), 156- 
163. https://doi.org/10.1016/j. jshs.2015.04.003

Clarabel R.C dan Contreras, A. P. (2014). Assessment of Environmental Literacy, Concern and Disaster Preparedness Among College Students, 2(3), 1-11.

Derman, A., Sahin, E., \& Hacieminoglu, E. (2016). Does Outdoor Education Make any Difference in Environmental Literacy of Preservice Classroom Teachers?, 11(15), 8491-8506.

Every, E., \& Student, C. (2015).ABlueprint For Environmental Literacy.

Holdaway, D. (1979). The foundations of literacy (Vol. 138). Sydney: Ashton Scholastic

Fidan, N. K. (2016). Acquisition of Operational Environmental Literacy in, 11(13), 5951-5968

Haske, A. S., \& Wulan, A. R. (2015). Pengembangan E-learning berbasis MOODLE dalam Pembelajaran Ekosistem untuk Meningkatkan Literasi Lingkungan Siswa pada Program Pengayaan, 402-409.

Karimzadegan, H., \& Meiboudi, H. (2012). Exploration of environmental literacy in science education curriculum in primary schools in Iran, 46, 404-409. https://doi. org/10.1016/j.sbspro.2012.05.131

Loubser, C. P., Swanepoel, C. H., Chacko, C. P. C. (2001). Concept formulation for environmental literacy. South African Journal of Education. 21(4), 317-323.

Luppi, E. (2011). Training to Education for Sustainable Development through e-learning. Procedia-Social and Behavioral Sciences, 15, 32443251. https://doi.org/10.1016/j. sbspro.2011.04.279

Ozge, H., Moseley, C., \& Cigdemoglu, C. (2011). Taking attention on environmental issues by an attractive educational game: enviropoly. Procedia - Social and Behavioral Sciences, 28, 801-806. https://doi. org/10.1016/j.sbspro.2011.11.146

Rahmawati, N. A., \& Suyanto, T. (2016). Kepemimpinan Kepala Desa Jombangdelik Kecamatan Balongpanggang Kabupaten Gresik dalam Mendorong Partisipasi Masyarakat pada Pengelolaan Lingkungan. Jurnal Mahasiswa Teknologi Pendidikan, 2(4) 